\title{
DNA DAMAGE BY OXIDIZED FATTY ACIDS DETECTED BY DNA/SPE BIOSENSOR
}

\author{
LUDMILA SIROTOVÁ, MARCELA MATULOVÁ \\ Food Research Institute, Department Biocentre, Kostolná 7, SK- 90001 Modra, \\ SlovakRepublic (sirotova@vup.sk)
}

\begin{abstract}
Electrochemical DNA/screen-printed electrode biosensor (DNA/SPE biosensor) was tested for the detection of alterations in DNA formed as a consequence of the reaction between DNA and oxidative products of fatty acids. Interaction of DNA with a mixture of products generated during the oxidation of linoleic and oleic acids manifested DNA damage depending on a tested fatty acid and the presence of hydroperoxides and thiobarbituric acid reactive substances (TBARS) determined after the oxidation of fatty acids. A bigger extent of the DNA damage was registered in the case of the interaction with oxidized linoleic acid with the high content of TBARS. The results achieved suggest the possible application of DNA/SPE biosensor in the detection of an interaction between DNA and products of fatty acid oxidation.
\end{abstract}

Key words: DNA/SPE biosensor, fatty acid oxidation, DNA damage

\section{Introduction}

The damage of DNA and its consequences have become the closely observed topics in the last years (MARNETT, 2000; MARNETT et al., 2003). Mutagenicity and genotoxicity of various endogenous and exogenous reactive compounds acting on DNA have been connected with ageing, the formation of such illnesses as cancer, cardiovascular and neurodegenerative diseases and immune system decline (HWANG and BOWEN, 2007). Some of the studies suggest that the oxidation of fatty acids and the consequent DNA damage play an important role in such processes (MARNETT, 2002; KANNER, 2007). The polyunsaturated fatty acids are extremely sensitive to attack of reactive oxygen species. The first products of polyunsaturated fatty acid oxidation are relatively short-lived lipid hydroperoxides. They are reduced to unreactive fatty acid alcohols or react with metals to aldehydes, ketones, alcohols, short fatty acids, esters, hydrocarbons, furans, and lactones, named as secondary products (BURCHAM, 1998). Some products are rather long-lived and can drift far from membranes and damage nucleic acids. DNA damages may occur as single-strand breaks, double-strand breaks, abasic site formation, sister chromatide exchange, DNADNA and DNA-protein cross-links, damages to deoxyribose and base adduct formation. The phosphodiester backbone can be also damaged, leaving abnormal ends. Such alterations to DNA have been shown to disrupt transcription, translation, DNA replication and lead to mutations, cell senescence or death (TERMINI, 2000; BLAIR, 2001).

Methods used for evaluation of DNA damage assess the overall state of DNA (cleavage of DNA strand, changes in structure, presence of bound compounds affecting the properties of DNA) or they are based on detecting the formed adducts. Gel electrophoresis (BOZKO et al., 2005; PHILIPS et al., 2005) and Comet assay (detection of cell DNA damage) (GONTIJO et al., 2001) are the methods currently 
employed for assessing the changes in DNA. Methods for detection of formed adducts allow qualitative and quantitative assessment of damage of individual bases. The detection of the adducts is possible using ${ }^{32} \mathrm{P}$-postlabelling HPLC method (NATH et al., 1996), by the chromatographic techniques as gas chromatography/electron capture/negative chemical ionization/mass spectrometry (GC/EC NCI/MS) (ROUZER et al., 1997), liquid chromatography with electrospray tandem mass spectrometry (LC/ESI-MS/MS) (CHAUDHARY et al., 1995; JEONG et al., 2005; SINGH and FARMER, 2006) or by immunochemical techniques (KAWAI et al., 2002).

Biosensors bring the new possibilities in the area of monitoring of the DNA damage (DRUMMOND et al., 2003). Particularly electrochemical DNA/screen printed electrode biosensor (DNA/SPE biosensor) constitutes a device for a rapid, cheap but sensitive detection of the changes on DNA (TUDORACHE and BALA, 2007). The detection schemes are based on a redox signal of the DNA base (adenine or often guanine) (XIE et al., 2007) and/or the special electrochemical indicators (TANSIL et al., 2005; NIU et al., 2006). Biosensors have been applied for observing of the alterations of DNA due to multiple chemical nucleases, antibiotics (LABUDA et al., 2000), samples from the environment (MASCINI, 2001) and have also been used for observing the impacts of the antioxidatively active substances on DNA (HEILEROVÁ et al., 2003; LABUDA et al., 2003; LIU et al., 2006). In our study we have tested DNA/SPE biosensor as a detection system for the assessment of the influence of oxidized fatty acids on DNA.

\section{Material and methods}

\subsection{Materials}

Oleic acid, linoleic acid and Tween 20 were purchased from Sigma (Steinheim, Germany). Stock solution of calf thymus DNA (Calbiochem, Darmstadt, Germany) 1 mg. $\mathrm{ml}^{-1}$ was prepared in TE solution $(10 \mathrm{mM}$ Tris-HCl with $1 \mathrm{mM}$ EDTA, pH 8). Electrochemical marker $\left[\mathrm{Co}(\text { phen })_{3}\right] \mathrm{ClO}_{4}$ was supplied by FCHPT STU (Bratislava, Slovakia). All other chemicals were of analytical grade.

\subsection{Fatty acid oxidation}

Both linoleic and oleic acid (3 g) were oxidized in Rancimat 743 (Metrohm, Herisau, Switzerland) test tube at $150^{\circ} \mathrm{C}$ for $4 \mathrm{~h}$. The amount of $0.01 \mathrm{~g}$ of oxidized fatty acid was homogenized with $100 \mu \mathrm{l}$ of Tween 20 solution $(0.5 \mathrm{~g} / 10 \mathrm{ml}$ deionized water).

\subsection{Peroxide value determination}

Peroxide value was determined by the IDF method (SHANTHA and DECKER, 1994). Briefly, oxidized fatty acid (0.01-0.3 g) was mixed in test tube with a mixture of chloroform:methanol 7:3 (v/v). Then $\mathrm{NH}_{4} \mathrm{SCN}$ and subsequently $\mathrm{Fe}(\mathrm{II})$ solutions were added to the fatty acid solution. The absorbance was measured 
spectrophotometrically at $500 \mathrm{~nm}$ against blank solution after 5 min incubation of the mixture in dark. Peroxide value was expressed in milliequivalents of peroxides per $\mathrm{kg}$ of fatty acid.

\subsection{TBARS value determination}

Oxidized fatty acid and $2 \mathrm{ml}$ of each $1 \%$ TBA and $20 \%$ iced acetic acid and $1 \mathrm{ml}$ of deionized water were added to the mixture and then heated in a water bath to $100^{\circ} \mathrm{C}$ for $1 \mathrm{~h}$. After cooling, $5 \mathrm{ml}$ of chloroform were added to the mixture, then the entire mixture was centrifuged at $2000 \mathrm{xg}$ for $10 \mathrm{~min}$. The absorbance of supernatant was measured spectrophotometrically at $532 \mathrm{~nm}$. The value of TBARS was expressed in nmol of MDA equivalent per $\mathrm{g}$ of fatty acid.

\subsection{DNA/SPE biosensor}

A computerized voltammentric analyzer EcaPol 110 (Istran, Bratislava, Slovakia) was equipped by a screen-printed three electrode assembly (VUP Biocemtrum, Modra, Slovakia) including a carbon working electrode and the silver/silver chloride reference and counter electrodes. The working electrode, used without any chemical preconditioning, was modified by covering with $5 \mu \mathrm{l}$ of the DNA stock solution and leaving the electrode to dry overnight. DNA/SPE biosensor was pretreated by immersion in $5 \mathrm{mM}$ phosphate buffer $\mathrm{pH} 7.0$ under stirring for $2 \mathrm{~min}$, then rinsed with water. The $\left[\mathrm{Co}(\text { phen })_{3}\right]^{3+}$ indicator was accumulated under stirring for $120 \mathrm{~s}$ at an open circuit from $5 \mathrm{ml}$ of its $5.10^{-5} \mathrm{M}$ solution in $5 \mathrm{mM}$ phosphate buffer. The differential pulse voltammogram (DPV) was recorded immediately from 400 to $-400 \mathrm{mV}$ at a pulze amplitude of $100 \mathrm{mV}$ and $2 \mathrm{mV}$ scan step at the scan rate of $25 \mathrm{mV} / \mathrm{s}$. The indicator peak current $\left(\mathrm{I}_{0}\right)$ was evaluated against the base-line using analyzer software and corrected by a subtraction of the mean indicator peak current measured at the unmodified SPE under the same conditions. Then, the DNA/SPE biosensor was regenerated by a removal of the accumulated $\left[\mathrm{Co}(\text { phen })_{3}\right]^{3+}$ ions from the DNA layer by treating the sensor in $100 \mathrm{mM}$ phosphate buffer $\mathrm{pH} 7.0$ under stirring for $120 \mathrm{~s}$. The peak current $\mathrm{I}_{0}$ was obtained in triplicate.

The DNA layer was covered with $5 \mu \mathrm{l}$ of the oxidized fatty acid sample. After 20 min the DNA/SPE biosensor was treated for $120 \mathrm{~s}$ in surfactant solution $(0.5 \mathrm{~g} / 100 \mathrm{ml}$ deionized water) (Procter and Gamble, Rakona, Czech Republic) under stirring at open circuit conditions. The sensor was rinsed with deionized water and then immersed into $5 \mathrm{mM}$ phosphate buffer with $\left[\mathrm{Co}(\text { phen })_{3}\right]^{3+}$ indicator for $120 \mathrm{~s}$ for its immobilization. The DPV was recorded immediately at the same conditions as above. The peak current I was obtained in triplicate.

The degree of DNA damage was expressed as the ratio $\mathrm{I} / \mathrm{I}_{0}$, the indicator peak current after interaction of DNA with oxidized fatty acid (I) against the indicator peak current of unmodified DNA on $\operatorname{SPE}\left(\mathrm{I}_{0}\right)$. Both I and $\mathrm{I}_{0}$ were corrected by a subtraction of the mean indicator peak current measured at the unmodified SPE under the same conditions. 


\subsection{Statistical analysis}

All data are expressed as the mean \pm standard deviation. All raw data were processed using standard MS-EXCEL statistical package.

\section{Results and Discussion}

DNA immobilized on a screen-printed electrode interacted with the solution of oxidized linoleic and oleic acid. The interaction was evaluated using the current response signal of the electrochemical intercalating indicator $\left[\mathrm{Co}(\mathrm{phen})_{3}\right]^{3+}$ measured by the DPV technique. A drop in the current response of the indicator indicates the damage of a DNA strand or the presence of a competing compound, creating the steric obstacles to the intercalation of the indicator. The lower value of $\mathrm{I} / \mathrm{I}_{0}$ ratio the bigger DNA damage occurs.

The DNA damage by oxidized linoleic and oleic acids is showed in Fig. 1. The extent of the DNA damage was dependent on the conditions of the fatty acid oxidation. The influence of unoxidized fatty acids under the selected conditions showed a moderate decrease in the current response signal of the indicator (by $13 \%$ for linoleic acid and by $3 \%$ for oleic acid). This could be due to the oxidative products already present in the samples, what can be confirmed by PV (peroxide value) and TBARS (thiobarbituric acid reactive substances) values determined for the respective fatty acids (Fig. 2 and 3). The DNA damage was bigger with the increasing time of oxidation of the tested fatty acid. The course of this dependence had an exponential character. After a 4-hour oxidation the current response signal of the indicator was lowered by $57 \%$ in the case of linoleic acid and by $48 \%$ for oleic acid. The achieved degree of the DNA damage is a result of the interaction between the products formed in the respective stage of fatty acid oxidation and their reactivity towards DNA. The DNA/SPE biosensor detected the bigger extent of the DNA damage in the case of the reaction mixture of oxidized linoleic acid compared to oxidized oleic acid.

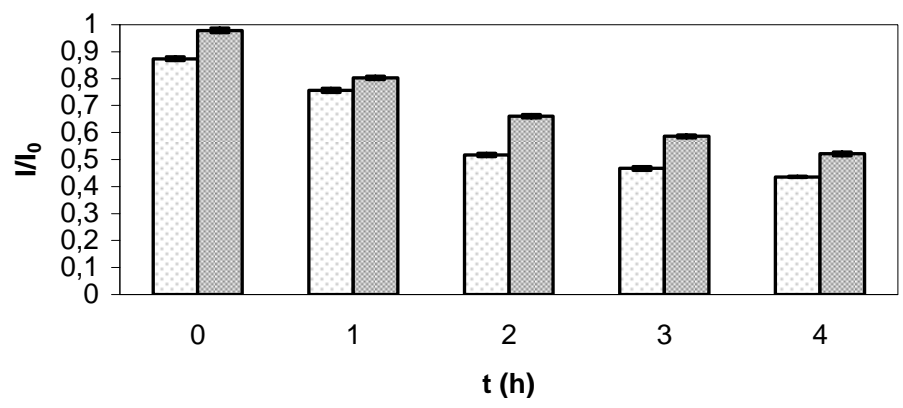

$\square$ linoleic acid $\square$ oleic acid

Fig. 1: The dependence of the DNA damage on the time of fatty acid oxidation assessed by DNA/SPE biosensor. 
During oxidation of fatty acids a mixture of products is formed depending on the type of fatty acid and the conditions of oxidation. Oxidation of fatty acids may be initiated by various ways, such as the presence of reactive oxygen species or other oxidatively active compounds, the activity of the specific enzymes or the increased temperature. As a consequence of oxidation of fatty acid, primary carbon centered radicals $\mathrm{L} \cdot$ are produced to give rise to peroxyl radicals LOO $\bullet$ which are transformed to hydroperoxides $\mathrm{LOOH}$. These compounds are further transformed to alkoxyl radicals $\mathrm{LO} \cdot$ or decompose rapidly into a multitude of volatile and non-volatile products. Alcohols, saturated aldehydes, $\alpha, \beta$-unsaturated aldehydes and epoxy compounds have been reported as the major secondary oxidation products (FRANKEL et al., 1992; BURCHAM, 1998). The presence of the respective compounds determines the degree of fatty acid oxidation and this can be detected by laboratory tests such as determination of the peroxide value (determines the amount of hydroperoxides produced - primary products) or TBARS value (determines the amount of substances able to react with thiobarbituric acid - secondary products).

The comparison of linoleic and oleic acid shows that with the increasing time of oxidation the peroxide value fell but the TBARS value rose (Fig. 2 and 3). At the same time, the peroxide value was higher in the case of oleic acid, while the TBARS value was higher for linoleic acid. A drop in the peroxide value and a rise in the TBARS value indicate the successive transformation of hydroperoxides of fatty acids to the secondary products. This transformation is more noticeable in the case of linoleic acid compared with oleic acid. This can be explained by the fact that linoleic acid is more prone to oxidation when compared to oleic acid because of the higher number of multiple bonds.

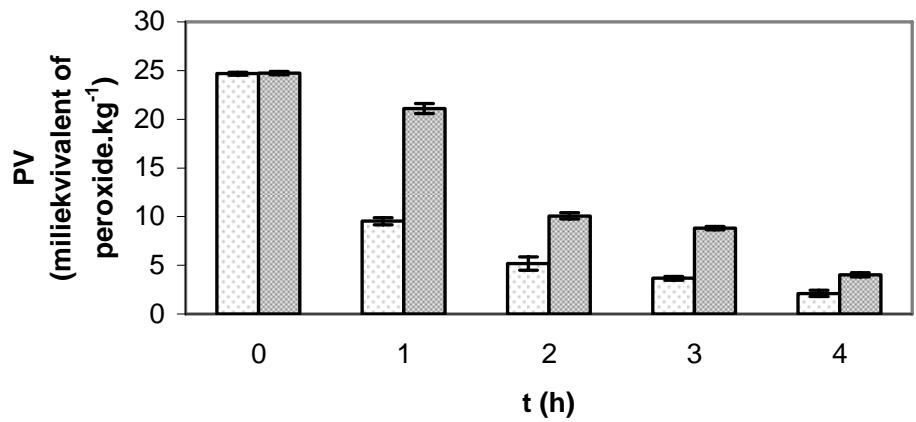

$\square$ linoleic acid $\square$ oleic acid

Fig. 2: Peroxide value of oxidized fatty acids.

Based on the comparison of a mixture of oxidized fatty acids and the DNA damage it is possible to suggest that under the selected conditions the presence of the secondary products has a more significant influence on the DNA damage than the presence of hydroperoxides. The extent of the DNA damage is increased with the increasing TBARS value. Studies on interactions between the DNA and hydroperoxides indicate that these compounds react with the DNA and cause cleavage 
of the double-stranded DNA or formation of the hydroperoxide-induced DNA adduct (TERMINI, 2000; BLAIR, 2001; KAWAI et al., 2002; WILLIAMS et al., 2006).

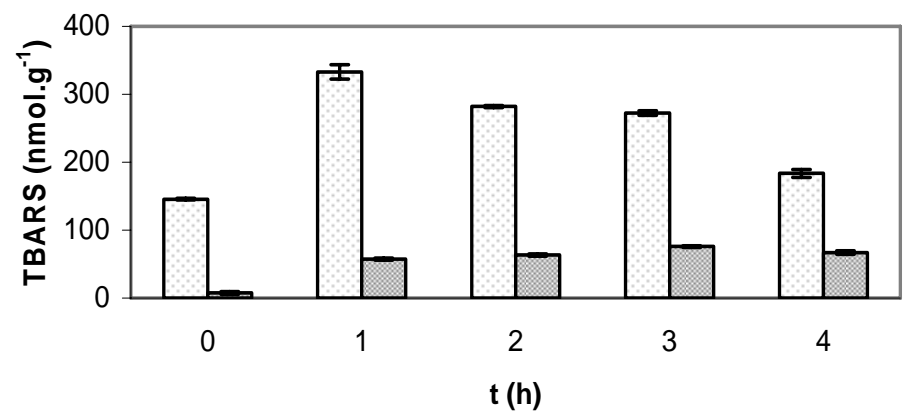

$\square$ linoleic acid $\square$ oleic acid

Fig. 3: TBARS amount in oxidized fatty acids.

Base adducts are preferentially formed by $\alpha, \beta$-unsaturated aldehydes, ketones and their epoxides and alkenes (EIDE et al., 1995). Especially the adducts with acrolein, crotonaldehyde (MARNETT, 1994), malondialdehyde (MDA) (MARNETT, 1999) and 4-hydroxy-2-nonenal (YANG et al., 2003), which serve as biomarkers of certain diseases have been thoroughly studied. Therefore, the lowered current response signal of the indicator could be the result of the structural changes in the DNA strand or due to the base adducts formed, which hinder the indicator from intercalating into the minor and major grooves of DNA.

\section{Conclusions}

Under the selected conditions DNA/SPE biosensor sensitively responded to the DNA damage caused by oxidized linoleic and oleic acids. Though the biosensor and the given indicator system does not enable to define the concrete type of the DNA damage, it can be used for proving the oxidative alterations in fatty acids or other lipidic samples. To effectively use the biosensor for evaluation of interactions between DNA and the oxidative products of fatty acids it is important to take into consideration reactivity of individual generated products towards DNA, a mechanism of their action, a type of the damage they cause and the selection of the proper technique and indicator for detection of the DNA damage. The mentioned parameters are a subject of further studies.

Acknowledgement: This work was supported by Science and Technology Assistance Agency under the contact No. APVT-27-010304.

\section{References}

BLAIR, I.: Lipid hydroperoxide-mediated DNA damage. Exp. Geront., 36, 2001, 1473-1481. 
BOZKO, P., SABISZ, M., LARSEN, A.K., SKLADANOWSKI, A.: Cross-talk between DNA damage and cell survival checkpoints during G2 and mitosis: pharmacologic implications. Mol. Cancer Ther., 4, 2005, 2016-2025.

BURCHAM, P.C.: Genotoxic lipid peroxidation products: their DNA damaging properties and role in formation of endogenous DNA adducts. Mut., 13, 1998, 287305.

CHAUDHARY, A.K., NOKUBO, M., OGLESBY, T.D., MARNETT, L.J., BLAIR, I.A.: Characterization of endogenous DNA adducts by liquid chromatography/electron ionization tandem mass spectrometry. J. Mass Spectrom., 30, 1995, 1157-1166.

DRUMMOND, T.G., HILL, M.G., BARTON, J.K.: Electrochemical DNA sensors. Nat. Biotech., 21, 2003, 1192-1199.

EIDE, I., HAGEMANN, R., ZAHLSEN, K., TAREKE, E., TÖRNQVIST, M., KUMAR, R., VODICKA, P., HEMMINKI, K.: Uptake, distribution, and formation of hemoglobin and DNA adducts after inhalation of C2-C8 1-alkenes (olefins) in the rat. Carcinogenesis, 16, 1995, 1603-1609.

FRANKEL, E.N., SELKE, E., NEFF, W.E., MIYASHITA, K.: Autoxidation of polyunsaturated triacylglycerols. IV. Volatile decomposition products from triacylglycerols containing linoleate and linolenate. Lipids, 27, 1992, 442-446.

GONTIJO, A.M.M.C., ELIAS, F.N., SALVADORI, D.M.F., DE OLIVEIRA, M.L.C.S., CORREA, L.A., GOLDBERG, J., TRINDADE, J.C.S., DE CAMARGO, J.L.V.: Single-Cell Gel (Comet) Assay Detects Primary DNA Damage in Nonneoplastic Urothelial Cells of Smokers and Ex-smokers. Cancer Epidemiol. Biomarkers Prev., 10, 2001, 987-993.

HEILEROVÁ, L', BUČKOVÁ, M., TARAPČÍK, P., ŠILHÁR, S., LABUDA, J.: Comparison of Antioxidative Activity Data for Aqueous Extracts of Lemon Balm (Melissa officinalis L.), Oregano (Origanum vulgare L.), Thyme (Thymus vulgaris L.), and Agrimony (Agrimonia eupatoria L.) obtained by Conventional Methods and the DNA-Based Biosensor. Czech J. Food Sci., 21, 2003, 78-84.

HWANG, E.S., BOWEN, P.E.: DNA damage, a biomarker of carcinogenesis: its measurement and modulation by diet and environment. Crit. Rev. Food Sci. Nutr., 47, 2007, 27-50.

JEONG, Y.CH., SANGAIAH, R., NAKAMURA, J., PACHKOWSKI, B.F., RANASINGHE, A., GOLD, A., BALL, A.G., SWENBERG, J.A.: Analysis of $\mathrm{M}_{1} \mathrm{G}-\mathrm{dR}$ in DNA aldehyde reactive probe labeling and liquid chromatography tandem mass spectrometry. Chem. Res. Toxicol., 18, 2005, 51-60.

KANNER, J.: Dietary advanced lipid oxidation endproducts are risk factors for human health. Mol. Nutr. Food Res., 51, 2007, 1094-1104.

KAWAI, Y., KATO, Y., NAKAE, D., KUSUOKA, O., KONISHI, Y., UCHIDA, K., OSAWA, T.: Immunohistochemical detection of a substitued $1, \mathrm{~N}^{2}$ ethenodeoxyguanosine adduct by $\omega-6$ polyunsaturated fatty acid hydroperoxides in the liver of rats fed a choline-deficient, L-amino acid-defined diet. Carcinogenesis, 23, 2002, 485-489.

LABUDA, J., BUČKOVÁ, M., JANTOVÁ, S., ŠTEPÁNEK, I., SURUGIU, I., DANIELSSON, B., MASCINI, M.: Modified screen-printed electrodes for the 
investigation of the interaction of non-electroactive quinazoline derivatives with DNA. Fres. J. Anal. Chem., 367, 2000, 364-368.

LABUDA, J., BUČKOVÁ, M., HEILEROVÁ, L., ŠILHÁR, S., ŠTEPÁNEK, I.: Evaluation of the redox properties and anti/pro-oxidant effects of selected flavonoids by means of a DNA-based electrochemical biosensor. Anal. Bioanal. Chem., 376, 2003, 168-173.

LIU, J., SU, B., LAGGER, G., TACCHINNI, P., GIRAULT, H.: Antioxidant redox sensors based on DNA modified carbon screen-printed electrodes. Anal. Chem., 78, 2006, 6979-6884.

MARNETT, L.J.: DNA adduct of $\alpha, \beta$-unsaturated aldehydes and dicarbonyl compounds. JARC Scientific Publications, 125, 1994, 151-163.

MARNETT, L.J.: Lipid peroxidation-DNA damage by malondialdehyde. Mut. Res., 424, 1999, 83-95.

MARNETT, J.M.: Oxyradicals and DNA damage. Carcinogenesis, 21, 2000, 361-370.

MARNETT, L.J.: Oxy radicals, lipid peroxidation and DNA damage. Toxicology, 181-182, 2002, 219-222.

MARNETT, L.J., RIGGINS, J.N., WEST, J.D.: Endogenous generation of reactive oxidants and electrophiles and their reaction with DNA and protein. J. Clin. Invest., 111, 2003, 583-593.

MASCINI, M.: Affinity electrochemical biosensors for pollution control. Pure \& App. Chem., 73, 2001, 23-30.

NATH, R.G.; OCANDO, J.E. CHUNG, F.L.: Detection of $1, \mathrm{~N}^{2}$ propanodeoxyguanosine adducts as potential endogenous DNA lesion in rodent and human tissues. Canc. Res., 1996, 56, 452-456.

NIU, S., LI, F., ZHANG, S., WANG, L., LI, X., WANG, S.: Studies on the interaction mechanism of 1,10-phenanthroline cobalt(II) complex with DNA and preparation of electrochemical DNA biosensor. Sensors, 6, 2006, 1234-1244.

PHILIPS, B.J., CHANG, A.Y., DERVAN, P.B., BEERMAN, T.A.: DNA Damage Effects of a Polyamide-CBI Conjugate in SV40 Virions. Mol. Pharmacol., 67, 2005, 877-882.

ROUZER, C. A., CHAUDHARY, A.K., NOKUBO, M., FERGUSON, D.M.: Analysis of the malondialdehyde-2'-deoxyguanosine adduct pyrimidopurinone in human leucocyte DNA by gas chromatography/electron capture/negative chemical ionisation/mass spectrometry. Chem. Res. Toxicol., 10, 1997, 181-188.

SHANTHA, N.C., DECKER, E.A.: Rapid Sensitive Iron-bases Spectrophotometric Methods for the Determination of Peroxide Values in Food Lipids. J. Assoc. Offic. Anal. Chem. Intl., 77, 1994, 421-424.

SINGH, R., FARMER, P.B.: Liquid chromatography-electrospray ionization-mass spectrometry: the future of DNA adduct detection. Carcinogenesis, 27, 2006, 178-196.

TANSIL, N.C., XIE, H., XIE, F., GAO, Z.: Direct detection of DNA with an electrocatalytic threading intercalator. Anal. Chem., 77, 2005, 126-134.

TERMINI, J.: Hydroperoxide-induced DNA damage and mutations. Mut. Res., 450, 2000, 107-124.

TUDORACHE, M., BALA, C.: Biosensors based on screen-printing technology and their application in environmental and food analysis. Anal. Bioanal. Chem., 388, 2007, 565-578. 
WILlIAMS, M.V., LEE, S.H., POLLACK, M., BLAIR, I.A.: Endogenous lipid hydroperoxide-mediated DNA-adduct formation in min mice. J. Biol. Chem., 281, 2006, 10127-10133.

XIE, H., YANG, D., HELLER, A., GAO, Z.: Electrocatalytic oxidation of guanine, guanosine and guanosine monophosphate. Biophys. J., 2007, L01-L02.

YANG, Y., SHARMA, R., SHARMA, A., AWASTHI, S., AWASTHI, Y.C.: Lipid peroxidation and cell cycle signaling: 4-hydroxynonenal, a key molecule in stress mediated signaling. Acta Bioch. Pol., 50, 2003, 319-336. 